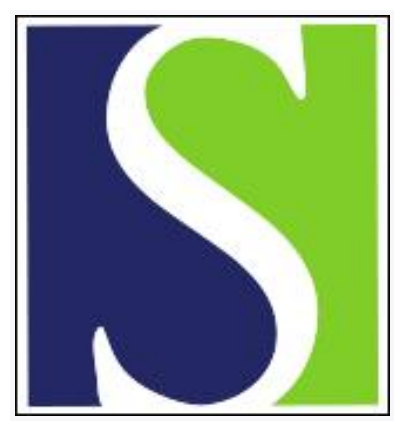

Scand J Work Environ Health 2004;30(3):199-205

https://doi.org/10.5271/sjweh.780

Issue date: Jun 2004

\title{
Costs of occupational injury and illness across industries
}

by Leigh JP, Waehrer G, Miller TR, Keenan C

Affiliation: Center for Health Services Research in Primary Care, 2103 Stockton Blvd, Suite 2224, Stockton, UC Davis Medical Center, Sacramento, CA 95817, USA. pleigh@ucdavis.edu

The following article refers to this text: 2009;35(6):401-402

Key terms: cost; economics; illness; industry; injury; job; occupational illness; occupational injury; Occupational Safety and Health Administration; OSHA

This article in PubMed: www.ncbi.nlm.nih.gov/pubmed/15250648 


\title{
Costs of occupational injury and illness across industries
}

\author{
by J Paul Leigh, PhD, ${ }^{1}$ Geetha Waehrer, PhD, ${ }^{2}$ Ted R Miller, PhD, ${ }^{2}$ Craig Keenan, MD³
}

\begin{abstract}
Leigh JP, Waehrer G, Miller TR, Keenan C. Costs of occupational injury and illness across industries. Scand J Work Environ Health 2003;30(3):199-205.
\end{abstract}

Objectives This study has ranked industries using estimated total costs and costs per worker.
Methods This incidence study of nationwide data was carried out in 1993. The main outcome measure was total
cost for medical care, lost productivity, and pain and suffering for the entire United States (US). The analysis was
conducted using fatal and nonfatal injury and illness data recorded in large data sets from the US Bureau of Labor
Statistics. Cost data were derived from workers' compensation records, estimates of lost wages, and jury awards.
Current-value calculations were used to express all costs in 1993 in US dollars.
Results The following industries were at the top of the list for average cost (cost per worker): taxicabs,
bituminous coal and lignite mining, logging, crushed stone, oil field services, water transportation services, sand
and gravel, and trucking. Industries high on the total-cost list were trucking, eating and drinking places, hospitals,
grocery stores, nursing homes, motor vehicles, and department stores. Industries at the bottom of the cost-per-
worker list included legal services, security brokers, mortgage bankers, security exchanges, and labor union
offices.
Conclusions Detailed methodology was developed for ranking industries by total cost and cost per worker.
Ranking by total costs provided information on total burden of hazards, and ranking by cost per worker provided
information on risk. Industries that ranked high on both lists deserve increased research and regulatory attention.

Key terms economics, jobs, Occupational Safety and Health Administration (OSHA).

Knowledge of the overall costs of occupational injuries and illnesses in the United States (US) has recently expanded (1-3). Nevertheless, little is known about which industries generate the most and the least costs. We are aware of only one study (4) that has attempted to rank industries according to cost, and it applied to only eight (US) states in the early 1980s. More information would be useful. For example, policy makers need to know where limited regulatory resources could be applied the most cost effectively (5).

Cost data can also provide information about such on-the-job risks as back injury, carpal tunnel syndrome, fracture, burn, gunshot wound, and even death. Adding the costs for these disparate injuries and illnesses is one way to summarize the risks. It is a useful summary. First, costs combine incidence with severity. Second, costs expressed in terms of a monetary value are easily understood by researchers, employers, and workers alike. Ranking industries by costs therefore increases the public's understanding of which jobs are dangerous.

\section{Material and methods}

The Annual Survey of Occupational Injuries and Illnesses of the US Bureau of Labor Statistics and its Census of Fatal Occupational Injuries were the two data sources that served as templates onto which we merged cost information (6, 7-9). The information on medical costs came from summaries of workers' compensation records in the Detailed Claims Information data set, the National Health Interview Survey, and prior work on medical costs for fatalities $(2,10)$. We transformed work loss information into US dollar values using wage data from

1 Center for Health Services Research in Primary Care and Department of Epidemiology and Preventive Medicine, University of California, Davis CA, United States.

2 Pacific Institute for Research and Evaluation, Calverton, Maryland, United States.

3 Department of General Internal Medicine, University of California, Davis, Medical Center, Sacramento, California, United States.

Reprint requests to: Dr J Paul Leigh, Center for Health Services Research in Primary Care, 2103 Stockton Blvd, Suite 2224, Stockton, UC Davis Medical Center, Sacramento, CA 95817, USA. [E-mail: pleigh@ucdavis.edu] 
the 1993 monthly Current Population Survey (11). We used a survey of jury verdicts related to occupational injuries and illnesses to predict pain and suffering costs for nonfatal cases (12-14).

In this article, we present a brief description of our methods. Thorough descriptions are available in appendices $\mathrm{A}$ and $\mathrm{B}$, available at the bottom of http://wwwepm.ucdavis.edu/Fac/Leigh/CostsAcrossIndustries.htm.

The 1993 Annual Survey contains detailed information on 603936 cases of nonfatal occupational injury and illness involving $\geq 1$ days away from work. It represents a total of 2.25 million such cases reported in the United States in 1993 in private industry among those not self-employed, not working on small farms, and not in private household occupations. The Survey does not contain information on government workers. Our cost estimates were based on a subset of 477643 cases. This subset was selected for two reasons. First, we excluded cases with days lost during the last 2 months of 1993. These November and December cases were excluded because there was a large artificial decrease in the number of lost workdays, perhaps as a result of the errors in the reports of work loss due to censoring or perhaps due to holidays in those months. Second, some data on days away from work could not be matched to medical cost data. So that our estimates would reflect the 2.2 million cases in the original sample, we re-scaled the case weights. (See appendix B at http://wwwepm.ucdavis.edu/Fac/Leigh/CostsAcrossIndustries.htm). Unlike the nonfatality data of the Annual Survey, no fatality data of the Census of Fatal Occupational Diseases $(\mathrm{N}=6271)$ were excluded.

The costs of occupational injuries and illnesses can be divided into the following three broad categories: direct costs, indirect costs, and quality-of-life costs. Direct costs include payments for hospitals, physicians and allied health services, rehabilitation, nursing home care, home health care, medical equipment, burial costs, insurance administrative costs for medical claims, payments for mental health treatment, police, fire, emergency transport, coroner services, and property damage. Indirect costs refer to (i) victim productivity losses, which include wage losses and household production losses, (ii) employer productivity losses, which include recruiting and training replacements for injured workers, and (iii) administrative costs, which include administering workers' compensation programs. Quality-oflife costs refer to the value attributed to pain and suffering by victims and families. For example, for women (and men) with carpal tunnel syndrome, the total average costs were USD 76697 (USD 87917 for men) and included wage losses of USD 22608 (USD 38314 for men), household production losses of USD 14124 (USD 6778 for men), medical costs of USD 3846 (USD 3846 for men), quality-of-life costs of USD 34374
(USD 36155 for men), and administration costs of USD 1745 (USD 2824 for men).

The costs were incidence-based and included costs over the victim's lifespan. Whenever costs extended over more than 1 year, we applied a discount rate of $2.5 \%$ to compute the current value.

Whereas the guiding principles for cost calculation for nonfatalities and fatalities were identical, the techniques of cost calculations differed. For nonfatal injuries, medical costs were estimated separately by diagnosis for those hospitalized and those not hospitalized (14). The medical costs for hospitalized victims were the product of five diagnosis-specific factors involving length of stay, hospital cost per day, the ratio of professional fee payments to hospital payments, the ratio of costs in the first 6 months to costs during the initial admission, and the ratio of the currrent value of lifetime medical payments to payments in the first 6 months. The medical costs for nonhospitalized victims were the product of five diagnosis-specific factors involving the probability that an injury or illness required medical treatment, the number of visits to physicians' offices, payments per nonhospitalized visit, the ratio of drug payments to payments for medical visits, and the ratio of current value of lifetime medical payments to payments in the first 6 months.

For nonfatal illnesses, medical costs were computed in a simpler manner since less information was available. The annual medical spending for hospitalization, for example, was computed as the product of the length of stay, the cost per day, and the ratio of hospital plus professional fee payments to hospital payments.

Indirect losses for nonfatal cases were divided into short- and long-term losses. To account for the censoring, we developed a statistical model to estimate the length of time censored cases would have taken to be resolved (appendix B at http://www-epm.ucdavis.edu/ Fac/Leigh/CostsAcrossIndustries.htm). The model predicted durations (length of time away from work) separately for 20 different injury and illness categories. Our adjustments resulted in an increase of approximately $12 \%$ for the overall estimate of days away from work. For short-term wage losses, we multiplied the number of days away from work by the predicted wage received by a worker of the same age group, race, gender, industry, and occupation as the injury victim (11).

We placed a zero dollar value on productivity losses among persons with restricted work (light duty). This was a conservative assumption since persons working on restricted duty were probably not producing as much as they would have been if they had been fully recuperated and working at their usual job.

The Annual Survey does not have information on disability status. Long-term wage losses resulting from permanent total disability were based on estimates of 
lifetime wage loss calculated according to an age-earnings model (15). For permanent partial cases, long-term wage loss was calculated by applying probabilities of permanent partial injuries and associated impairment fractions to estimated lifetime wage loss. We assumed cases in the Annual Survey were a fair reflection of the permanent disability cases.

We estimated the duration of household work loss by the number of days away from work times 365/243 times 0.9 (14). Marquis has shown that $90 \%$ of the time lost to wage work is also lost to household work (16).

We attributed a constant medical cost of USD 510 to medically treated cases without any work loss and a cost of USD 406 for cases with restricted work activities as derived from the National Health Interview Survey. Medical costs were attributed USD 12000 for each fatality (2). Lifetime household work losses were calculated using the specialist cost approach (17). We used estimates of the willingness-to-pay to avoid risk of fatal injury to determine pain and suffering costs (18).

\section{Results}

Table 1 presents the top 50 industries ranked according to average costs (ie, total costs divided by the number of workers). A total of 260 industries were ranked, and the complete list is available from the authors. The 50 industries in table 1, therefore, represent the upper $20 \%$.

Table 2 presents a ranking of the top 50 industries according to total costs. A total of 313 industries were ranked . These 50 industries, therefore, represent the top $16 \%$ of all the industries studied. We have more industries with total costs than with average costs because 53 of the industries did not have reliable denominator data. These 53 industries were all in the lower end of the list of 313 and were therefore "small" (ie, employing far fewer workers than the industries in the average cost list of 260 .

Table 3 presents the bottom 20 industries for the ranking of cost per worker. The bottom five of these 20 industries represent the lowest $8 \%$ of the 260 industries.

\section{Discussion}

We are aware of only one prior study that considers costs of occupational injuries and illnesses across industries (4). Our method improved on prior cost methodology by (i) relying on national data of the US Bureau of Labor Statistics rather than on the workers' compensation records of a few states, (ii) accounting for pain and suffering (quality of life) costs, (iii) using medical cost data that coincide with the diagnosis of injury or illness, (iv) using data from the 1990s rather than those of the 1980s, (v) using the Annual Survey and the Census of Fatal Occupational Injuries rather than workers'

Table 1. Average cost (cost per worker) for fatal and all nonfatal injuries and illnesses ranked by detailed industry. (SIC = 1987 standard industrial classification, USD = United States dollars, GDP = gross domestic product)

\begin{tabular}{ccc}
\hline Rank SIC Description of detailed industry & Average & Contri- \\
code & cost & bution \\
& per & to GDP \\
& worker & per em \\
& (USD) & ployed \\
& & worker
\end{tabular}

(\%)

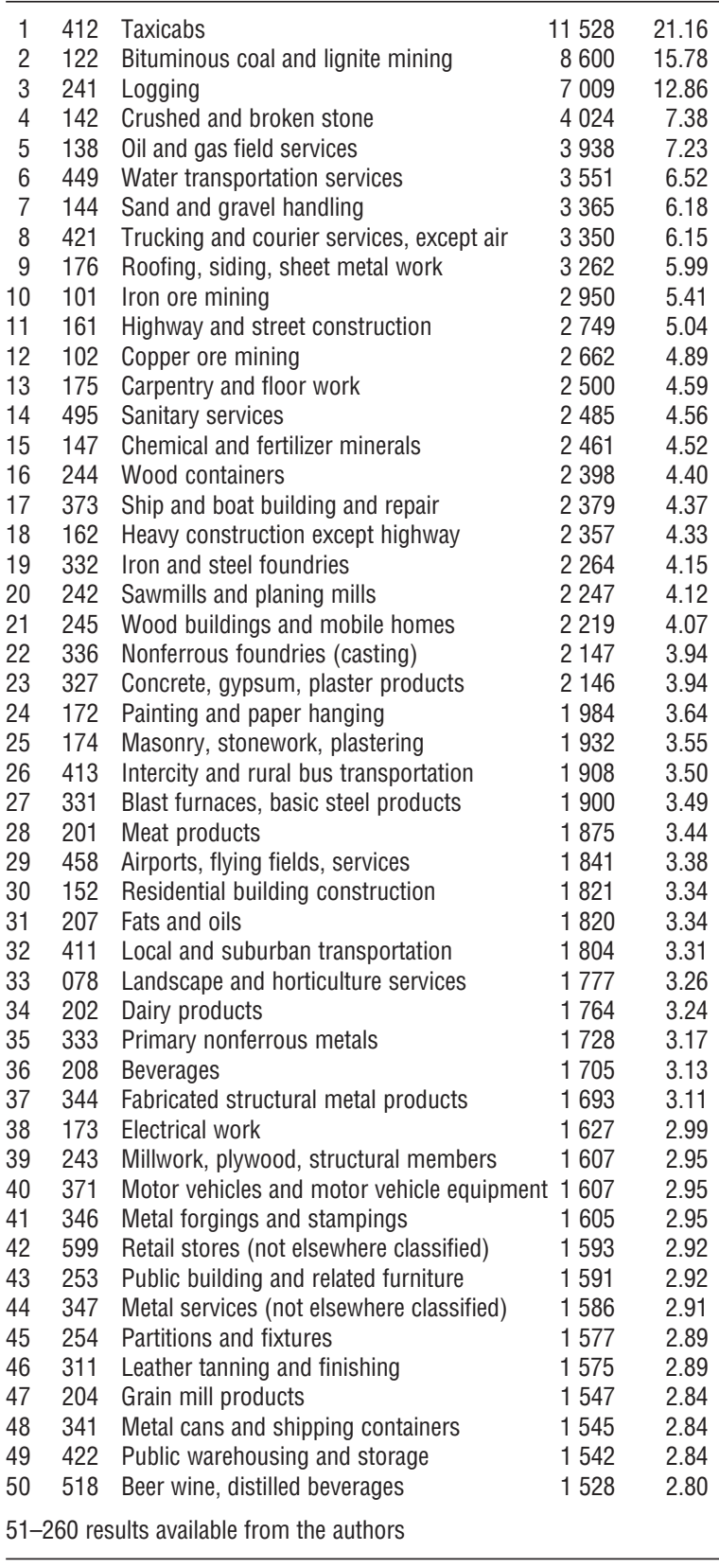

a GDP per employed worker = USD 54491. 
Table 2. Total costs for fatal and all nonfatal injuries and illnesses ranked by detailed industry (SIC = 1987 standard industrial classification, USD $=$ United States dollars, GDP $=$ gross domestic product)

\begin{tabular}{|c|c|c|c|c|}
\hline Rank & $\begin{array}{l}\text { SIC } \\
\text { code }\end{array}$ & Desc & $\begin{array}{l}\text { Total cost } \\
\text { (USD) }\end{array}$ & $\begin{array}{l}\text { GDP } \\
(\%)\end{array}$ \\
\hline 1 & 421 & $\begin{array}{l}\text { Trucking and courier services, } \\
\text { except air }\end{array}$ & 4394408812 & 0.0671 \\
\hline 2 & 58 & Eating and drinking places & 3245844489 & 0.0495 \\
\hline 3 & 806 & Hospitals & 2755633582 & 0.0421 \\
\hline 4 & 541 & Grocery stores & 2718377125 & 0.0414 \\
\hline 5 & 805 & Nursing and personal care facilities & 1943638220 & 0.0297 \\
\hline 6 & 371 & $\begin{array}{l}\text { Motor vehicles and motor vehicle } \\
\text { equipment }\end{array}$ & 1344070300 & 0.0205 \\
\hline 7 & 531 & Department stores & 1328163891 & 0.0203 \\
\hline 8 & 514 & Groceries and related products & 128 & 0.0197 \\
\hline 9 & 179 & ous special trades & 1168010753 & 0.0178 \\
\hline 10 & 162 & $\begin{array}{l}\text { Heavy construction, except } \\
\text { highway }\end{array}$ & 161 & 0.0176 \\
\hline 11 & 451 & Air transportation, scheduled & 348 & 0.0159 \\
\hline 12 & 152 & Residential building con & 02 & 0.0156 \\
\hline 13 & 701 & Hotels and motels & 1042 & 0.0155 \\
\hline 14 & 171 & $\begin{array}{l}\text { Plumbing, heating, air- } \\
\text { conditioning }\end{array}$ & 945249458 & 0.0144 \\
\hline 15 & 308 & $\begin{array}{l}\text { Miscell } \\
\text { (not els }\end{array}$ & 888 & 0.0136 \\
\hline 16 & 122 & oal and lignite mining & 00 & 0.0132 \\
\hline 17 & 738 & business services & & 0.0130 \\
\hline 18 & 173 & Electrical work & 697 & 0.0129 \\
\hline 19 & 201 & Meat products & 914 & 0.0127 \\
\hline 20 & 154 & $\begin{array}{l}\text { dential building } \\
\text { tion }\end{array}$ & 69 & 0.0122 \\
\hline 21 & 174 & tonowerk nl & & 0.0116 \\
\hline 22 & 551 & $\mathrm{Ne}$ & & 0.0107 \\
\hline 23 & 799 & ement, & 47794 & 0.0106 \\
\hline 24 & 138 & & & \\
\hline 25 & 599 & here & 770 & 0.0102 \\
\hline 26 & 344 & $\begin{array}{l}\text { Fabricated structural metal } \\
\text { products }\end{array}$ & 66 & 0.0102 \\
\hline 27 & 753 & Auto & 88 & 0.0102 \\
\hline 28 & 176 & $\begin{array}{l}\text { Roofing, siding and sheet } \\
\text { metal work }\end{array}$ & 65849 & 0.0100 \\
\hline 29 & 161 & detrest sonetr & & 0.0093 \\
\hline 30 & 078 & ape and horticultural & 447 & 0.0089 \\
\hline 31 & 241 & Logging & & \\
\hline 32 & 508 & Mac & 53 & 0.0083 \\
\hline 33 & 734 & Services to buildings & 206 & 0.0079 \\
\hline 34 & 736 & el supply s & 50 & 0.0077 \\
\hline 35 & 836 & Residential care & 478862899 & 0.0073 \\
\hline 36 & 372 & Aircr & 86 & 0.0071 \\
\hline 37 & 175 & Carpentry and floor & 464682897 & 0.0071 \\
\hline 38 & 651 & nd lessors & 75 & 0.0070 \\
\hline 39 & 481 & Telephone communications & 460928796 & 0.0070 \\
\hline 40 & 554 & stations & 307 & 0.0070 \\
\hline 41 & 331 & $\begin{array}{l}\text { Blast furnace and basic } \\
\text { steel products }\end{array}$ & 456537931 & 0.0070 \\
\hline 42 & 521 & Lumber and other building materials & & 0.0069 \\
\hline 43 & 275 & rcial printing & 7223 & 0.0066 \\
\hline 44 & 501 & Motor vehicles, parts, supplies & & 0.0064 \\
\hline 45 & 242 & Sawmills and planing mills & 408766749 & 0.0062 \\
\hline 46 & 243 & $\begin{array}{l}\text { Millwork, plywood, structural } \\
\text { members }\end{array}$ & 405117774 & 0.0062 \\
\hline 47 & 327 & , gypsum, plaster products & & 0.0062 \\
\hline 48 & 019 & General farm, primary crop & 403761352 & 0.0061 \\
\hline 49 & 449 & Water transportation services & & 0.0058 \\
\hline 50 & 373 & Ship and boat building and repairing & g 378563293 & 0.0058 \\
\hline \multicolumn{5}{|c|}{ ailable from } \\
\hline
\end{tabular}

Table 3. Average cost ranking of industries with the lowest costs per worker. ( $\mathrm{SIC}=1987$ standard industrial classification, USD = United States dollars, GDP = gross domestic product)

\begin{tabular}{rrlrc}
\hline Rank SIC & $\begin{array}{l}\text { Description } \\
\text { code }\end{array}$ & $\begin{array}{c}\text { Costs per } \\
\text { worker } \\
\text { (USD) }\end{array}$ & $\begin{array}{r}\text { GDP a } \\
(\%)\end{array}$ \\
\hline 1 & 863 & Labor union offices & 86 & 0.16 \\
2 & 623 & Security and commodity exchanges & 101 & 0.19 \\
3 & 616 & Mortgage bankers and brokers & 136 & 0.25 \\
4 & 621 & Security brokers and dealers & 137 & 0.25 \\
5 & 81 & Legal services & 138 & 0.25 \\
6 & 472 & Passenger transportation arrangements & 140 & 0.26 \\
7 & 801 & Offices and clinics of medical doctors & 146 & 0.27 \\
8 & 615 & Business credit institutions & 148 & 0.27 \\
9 & 64 & Insurance agents, brokers and services & 168 & 0.31 \\
10 & 737 & Computer and data processing services & 178 & 0.33 \\
11 & 211 & Tobacco & 180 & 0.33 \\
12 & 562 & Women's clothing stores & 186 & 0.34 \\
13 & 842 & Botanical and zoological gardens & 200 & 0.37 \\
14 & 671 & Holding offices & 201 & 0.37 \\
15 & 872 & Accounting, auditing, bookkeeping & 217 & 0.40 \\
16 & 633 & Fire, marine, casualty, insurance & 218 & 0.40 \\
17 & 632 & Medical services and health insurance & 219 & 0.40 \\
18 & 602 & Commercial banks & 232 & 0.43 \\
19 & 279 & Printing trade services & 233 & 0.43 \\
20 & 736 & Personnel supply services & 241 & 0.44 \\
\hline
\end{tabular}

a Per employed worker.

compensation data to count deaths. [The Annual Survey counts more than twice the deaths appearing in workers' compensation records.] But despite these differences, there were similarities between the prior 1980s study and this one. As regards the cost-per-worker lists, 28 of the top 50 industries in the prior study were also in the top 50 in this study. For total costs, 39 of the top 50 in the prior study were also in the top 50 in this study. Finally, both studies had the same top two industries for total costs, namely, trucking and eating and drinking places.

A few published studies and also "raw data" tables of the US Bureau of Labor Statistics attempt to rank industries by number as well as by rates of fatalities and nonfatal injuries $(6-9,19)$. But our rankings improved over these few studies and tables in that we were able to combine fatalities and nonfatalities into one easily understood metric-costs.

The ranking for average cost in table 1 was more likely to be influenced by fatalities than the ranking for total cost in table 2. A few deaths in an industry with low employment can result in high average costs. Taxicabs, coal mining, logging, crushed and broken stone, oil and gas field services, water transportation, sand and gravel, trucking, iron ore mining, highway construction, and copper ore mining consistently rank high on industry death-rate lists of the US Bureau of Labor Statistics (www.bls.gov/ iif/oshwc/cfoi0057.pdf) $(4,19,20)$. Taxicabs, coal mining, logging, highway construction, trucking, and sanitation have been subjected to in-depth analyses (21-26). 
The ranking of total costs in table 2, on the other hand, was likely to be more affected by the level of employment in the industry and the number and type of nonfatal injuries. Nonfatal injuries and illnesses comprise over $85 \%$ of all costs of occupational injuries and illnesses (27). For example, the list for total numbers of nonfatal injuries and illnesses in the 1994 Annual Survey and the Census of Fatal Occupational Injuries was eating and drinking places (1st in the Annual Survey and 2nd in table 2), hospitals (2nd in the Annual Survey and 3rd in table 2), trucking and courier services, except air (3rd in the Annual Survey and 21st in table 2), grocery stores (4th in the Annual Survey and 4th in table 2), nursing and personal care facilities (5th in the Annual Survey and 5th in table 2), motor vehicles manufacturing (6th in the Annual Survey and 6th in table 2), department stores (7th in the Annual Survey and 7th in table 2), hotels and motels (8th in the Annual Survey and 13th in table 2) (28). Some of these industries (retail stores, motor vehicle manufacturing, eating and drinking places) have already attracted research attention (29-31).

In general, the greater the numbers of injuries and the more serious the injuries, the higher the total cost and cost per worker. As a result, our results can be viewed as rankings of the combined hazards within industries. Several implications emanate from this "hazard" interpretation.

The first implication pertains to the health services sector. Two of the top five industries on the total list in table 2 are within this sector (hospitals and nursing and personal care facilities). Whereas neither of these appear in the top five on the average cost list, data on incidence rates of all injuries and illnesses in the Annual Survey suggest that average risks, especially for women, are relatively high in hospitals and nursing care facilities $(32,33)$. Given that these industries are in the business of providing health care, one would think they would be near the bottom in generating occupational injuries and illnesses. Our results support the finding of a report on patient safety in hospitals, namely, that the health care sector is not as safe as is generally assumed (34).

A second implication pertains to costs per worker. Industries with low average costs (table 3 and those in the bottom 100 of table 1) are probably much safer per worker than those with high average costs (top 50 in table 1). The industries at the top of table 1 tend to employ a higher percentage of blue-collar workers (crafts, trades, repair, operators, fabricators, laborers) than white-collar workers (brokers, lawyers, insurance agents, bankers). The difference in average costs (risks) was significant. For example, sanitary services ranked 14th in table 1. Commercial banks ranked 18th in table 3 . The ratio of their average cost is roughly $11: 1$. Given such a sharp difference in these rates, it is perhaps understandable that a typical banker would have trouble imagining that a typical garbage collector is exposed to serious and frequent hazards on the job.

A third implication pertains to regulatory direction. The Occupational Safety and Health Administration (OSHA) has limited resources to police industries. Currently, OSHA targets firms based on their nonfatal lostworkday rate, which does not account for deaths, medical costs, or lost wages. To have the greatest impact, OSHA might consider targeting their intervention towards industries that are high on both cost lists. These include trucking, motor vehicles, all construction industries, bituminous coal mining (Mine Safety and Health Administration), electrical work, meat products, masonry, roofing, landscaping, logging, carpentry, blast furnaces, sawmills, millwork, concrete products, water transportation, and ship building.

It is probably not cost-effective to use only one list for targeting. An industry with a high cost per worker may have low employment and thus expose only a few people to risks. But an industry with high employment and high total costs may be relatively safe, per worker. One possibility is to multiply the cost per worker with the total costs of each industry. A ranking of industries based on the product of these two statistics might be the most cost-effective list for targeting.

A fourth implication is that apparently the safest place to work is in the administrative office of a labor union.

A fifth implication is that workers' compensation insurers may find these data and especially this approach useful. Whereas the insurers maintain their own records on firms and industries, they typically do not keep data on all the costs included in our report, such as retaining costs, administrative costs, and lost quality of life.

Our study has limitations, however. The Annual Survey data we used excluded federal, state, and local government workers, workers on farms with fewer than 11 employees, and the self-employed. Moreover, economic incentives exist for workers to over- and underreport injuries and for employers to underreport. Whereas these limitations figure prominently in an estimate of national total costs for all industries combined, they are less prominent for an industry-by-industry ranking, if it is assumed that these limitations apply equally across industries.

Illnesses are likely to be severely underestimated. Workers' compensation is paid to people who worked immediately prior to the time of the injury or illness. If the illness does not manifest itself until retirement, it becomes difficult, if not impossible, in some states, to collect workers' compensation benefits. But many occupational diseases are not apparent until retirement (1). One of these is job-related osteoarthritis. Job-related injuries to joints early in life could result in osteoarthritis 
in these joints later in life. Job-related arthritis cost roughly USD 8.3 billion in 1994 (35).

Our data come from 1993. In the interim, some hazardous tasks may have been eliminated, while new hazards may have been created within the industries studied. Any such shifts could affect incidence and cost data. On the other hand, scrutiny of statistics in tables of the National Safety Council reveals considerable stability in industry rankings from year to year $(3,36,37)$.

Direct cost estimates rely heavily on workers' compensation costs and charges. Workers' compensation medical costs are alleged to be inflated (38) since the workers' compensation system is a fee-for-service plan. But these allegations have not fully adjusted for the costs to physicians and providers for the paperwork and litigation that accompanies workers' compensation claims (39). In any case, data on workers' compensation costs do have the advantage that costs and charges are virtually identical and few co-payments or deductibles apply.

In conclusion, this study introduced innovations in cost methodology, such as accounting for censoring in measuring days lost in the Annual Survey of Occupational Injuries and Illnesses and the Census of Fatal Occupational Injuries of the US Bureau of Labor Statistics. In addition, costs can be used as a measure of risk that combines deaths with nonfatal injuries and illness cases. As a measure of risk, an industry ranking by costs could be helpful for targeting industries for policy intervention, as well as for alerting workers of the hazards associated with specific jobs. Moreover, some industries are high on both the total and average cost lists. Therefore, they are probably the most dangerous industries. These industries should be candidates for greater attention from occupational safety and health regulators and researchers.

\section{Acknowledgments}

This study was funded in part by grants from the National Institute for Occupational Safety and Health (OHO3750-01 and OH07338-01).

We are indebted to Dina McHugh for the word processing.

\section{References}

1. Leigh JP, Markowitz SB, Fahs MC, Shin C, Landrigan PJ. Occupational injury and illness: estimates of costs, mortality and morbidity. Arch Internal Med 1997;157:1557-68.

2. Miller TR, Galbraith M. Costs of occupational injury in the US. Accid Anal Prev 1995;27(6):741-7.
3. National Safety Council. Injury (accident) facts, 1999. Itasca (IL) National Safety Council Press; 1999.

4. Leigh JP, Miller TR. Ranking industries based upon the costs of job-related injuries and diseases. In: Farquhar I, Sorkin A, Weir E, editors. Research in human capital and development, vol.12. Greenwich (CT): JAI Press; 1998.

5. Kane F. Maine 200-type programs spread throughout the US. Job Saf Health 1996;7(3):9-15.

6. Toscano G, Windau J. The changing character of fatal work injuries. Mon Labor Rev 1994;117(10):17-28.

7. US Bureau of Labor Statistics. Occupational injuries and illnesses in the US by industry, 1991. Washington (DC): US Department of Labor; US Government Printing Office; 1992. Bulletin 2328

8. US Bureau of Labor Statistics. Occupational injuries and illnesses: counts, rates and characteristics, 1992. Washington (DC): US Department of Labor; US Government Printing Office;1995. Bulletin 2455.

9. US Bureau of Labor Statistics. News: characteristics of injuries and illnesses resulting in the absence from work, 1994. Washington (DC): US Department of Labor; 1996. USDL 96-163.

10. Miller TR, Pindus NM, Douglass JB. Medically related motor-vehicle injury costs by body region and severity. J Trauma 1993;34(2):270-5.

11. Weinberg DH, Nelson CT, Roemer MI, Welniak, EJ. Fifty years of data from the current population survey: alternatives, trends and quality. Am Econ Rev 1999; 89(2): 18-22.

12. Rodgers GB. Estimating jury compensation for pain and suffering in product liability cases involving nonfatal personal injury. J Forensic Econ 1993;6(3):251-62.

13. Miller TR, Cohen MA, Wiersema B. Victim costs and consequences: a new look. Washington (DC): Government Printing Office (GPO); 1996. National Institute of Justice Research Report NCJ 155281 \& US GPO: 1996-495-037/ 20041.

14. Miller TR, Lawrence BA, Jensen AF, Waehrer G, Spicer R, Lestina D. The Consumer Product Safety Commission's revised injury cost model [final report]. Washington (DC): Consumer Product Safety Commission; 1998.

15. Hodgson TA, Meiners MR. Cost of illness methodology-a guide to current practices and procedures. Milbank Q 1982; 60(3):429-62.

16. Marguis MS. Economic consequences of work related injuries. Santa Monica (CA): Rand Institute of Civil Justice; 1992. Report no CT-103.

17. Douglas J, Kenny G, Miller TR. Which estimates of household production are best? J Forensic Econ 1990;4(1):25-46.

18. Miller TR. The plausible range for the value of life: red herrings among the mackerel. J Forensic Econ 1990;3(3):1740 .

19. Leigh JP. Causes of death in the workplace. Westport (CT): Quorum; 1995.

20. Toscano G, Windau J. National census of fatal occupational injuries, 1995. Compens Work Cond 1996;48(3):34-45.

21. Knestant AT. Fatalities and injuries among truck and taxicab drivers. Compens Work Cond 1997;49(3):54-60.

22. Webster T. Work-related injuries, illnesses, and fatalities in manufacturing and construction. Compens Work Cond 1999;51(3):34-7.

23. McDermott D. Workplace injuries and illnesses in the extractive industries. Compens Work Cond 1997;49(1):57-61.

24. Sygnatur EF. Logging is perilous work. Compens Work Cond 1998;50(1):3-8 
25. Suarez P. The unforgiving road: trucker fatalities. Compens Work Cond 1999;51(1):27-32.

26. Drudi D. Job hazards in the waste industry. Compens Work Cond 1999;51(3):19-23.

27. Leigh JP, Markowitz SB, Fahs M, Landrigan PL. Costs of occupational injuries and illnesses. Ann Arbor (MI): University of Michigan Press; 2000.

28. US Bureau of Labor Statistics. News: workplace injuries and illnesses in 1994. 1995; USDL - 95-508 Released Friday, Dec 15.

29. Campany SO, Personick ME. Profiles in safety and health: retail stores. Mon Labor Rev 1992;115(9):9-16.

30. Jordan B. Safety and health risks of manufacturing motor vehicles and equipment. Compens Work Cond 1992;44(11):1-3.

31. Webster T. Occupational hazards in eating and drinking places. Compens Work Cond 2001;53(3):21-34.

32. Personick ME. Safety and health risks for hospital employees. Compens Work Cond 1993;45(4):1-3.
33. US Bureau of Labor Statistics. Occupational injuries and illnesses: counts, rates and characteristics; 1998. Washington (DC): US Department of Labor; 2000. Bulletin 2537.

34. Kohn LT, Dorrigan JM, Donaldson MS, editors. To err is human: building a safer health system. Washington (DC): National Academy Press; 2000.

35. Leigh JP, Seavey W, Leistikow B. Estimating the costs of job related arthritis. J Rheumatol 2001;28(7):1647-54.

36. National Safety Council. Accident facts, 1993. Itasca (IL): National Safety Council; 1993.

37. National Safety Council. Accident facts, 1995. Itasca (IL): National Safety Council; 1995.

38. Baker LC, Krueger AB. Medical costs in workers' compensation insurance. J Health Econ 1995;14(5):531-49.

39. Leigh JP, Ward MM. Medical costs in workers' compensation insurance: comment. J Health Econ 1997;16:612-22.

Received for publication: 17 March 2003 